UDC 631.31:631.51

\title{
SUPPLIES OF PRODUCTIVE MOISTURE AND YIELDING CAPACITY OF CROPS ROTATION DEPENDING ON THE SYSTEMS OF BASIC TILLAGE AND FERTILIZING
}

\author{
V. Kyryliuk ${ }^{1}$, T. Tymoshchuk ${ }^{2}$, H. Kotelnytska ${ }^{2}$, V. Barladiuha' ${ }^{2}$, D. Dolid ${ }^{2}$
}

Article info

Received

30.04.2020

Accepted

24.06.2020

${ }^{1}$ Khmelnitsky State Agricultural Experimental Station of the Institute of Feed Research and Agriculture of Podillya of NAAS

Samchyky village, Starokostyantynivsky district, Khmelnytsky region, 31182, Ukraine ${ }^{2}$ Zhytomyr National Agroecological University

7, Staryi Blvd, Zhytomyr, 10008, Ukraine

E-mail: hdsgds@ukr.net; tat-niktim@ukr.net
Kyryliuk, V., Tymoshchuk, T., Kotelnytska, H., Barladiuha, V., Dolid, D. (2020). Supplies of productive moisture and yielding capacity of crops rotation depending on the systems of basic tillage and fertilizing. Scientific Horizons, 07 (92), 141-148. doi: 10.33249/2663-2144-2020-92-7-141-148.

The main factor limiting the high productivity of agrophytocenoses of crops is accumulation of the productive moisture in the soil layer rich in roots, especially during the crucial periods of plant growth and development. The investigation into the impact of certain elements of agricultural technologies for cultivating crops on the soil water regime under conditions of the climate change is of pressing issue.

The paper presents results of the research into the influence of long-term application of systems of the basic tillage and fertilizing on the moisture supplies available to plants. The highest supplies of moisture available in the soil layer $0-20 \mathrm{~cm}$ were found in the chisel system of main cultivation in the stage of fully sprouted crops affected by mineral fertilizing. The supplies in the mouldboard plowing and shallow disk systems with indicators of $23.9 \mathrm{~mm}$ approximated to them. The highest reserves of available moisture were observed in shallow disk systems $(26.4 \mathrm{~mm})$.

In the middle stage of crop vegetation along with the mineral fertilizing the highest level of moisture available $(122.1 \mathrm{~mm})$ was found in a meter layer of soil under the mouldboard plowing system. The suppliers of moisture available $(129.2 \mathrm{~mm})$ in the mouldboard plowing system proved to be the highest under the same conditions of organic and mineral fertilizing.

The yielding capacity of white mustard (1.89 t/ha) and soybeans $(2.06 \mathrm{t} / \mathrm{ha})$ were the highest after mineral fertilizers applied in the mouldboard plowing system. The subsurface tillage system proved to be the best for obtaining high yield of spring barley (4.06 t/ha) and winter wheat (5.8 t/ha). The application of organic and mineral fertilizers promoted to the increase of yielding capacity of all crops with the corresponding indices $1.89 \mathrm{t} / \mathrm{ha}, 2.02 \mathrm{t} / \mathrm{ha}, 4.14 \mathrm{t} / \mathrm{ha}, 5.93 \mathrm{t} / \mathrm{ha}$ in the mouldboard plowing system.

Key words: productivity, white mustard, soybeans, winter wheat, spring barley, soil layer, nutrient status.

\section{ЗАПАСИ ПРОДУКТИВНОЇ ВОЛОГИ ТА УРОЖАЙНІСТЬ КУЛЬТУР СІВОЗМІНИ ЗАЛЕЖНО ВІД СИСТЕМ ОСНОВНОГО ОБРОБІТКУ ІРУНТУ ТА УДОБРЕННЯ}

\section{В. П. Кирилюк ${ }^{1}$, Т. М. Тимощук ${ }^{2}$ Г. М. Котельницька ${ }^{2}$ В. П. Барладюга ${ }^{2}$, Д. Є. Долід ${ }^{2}$ \\ ${ }^{1}$ Хмельницька державна сільськогосподарська дослідна станція \\ Інституту кормів та сільського господарства Поділля НААН \\ с. Самчики, Старокостянтинівський р-н, Хмельницька обл., 31182, Україна \\ ${ }^{2}$ Житомирський національний агроекологічний університет \\ бульвар Старий, 7, м. Житомир, 10008, Україна}

Основним фактором, що лімітуе отримання високої продуктивності агрофітоценозів сільськогосподарських культур є накопичення продуктивної вологи у кореневмісному шарі трунту, 
передусім у критичні періоди росту $і$ розвитку рослин. Актуальним є вивчення впливу окремих елементів агротехнологій вирощування сільськогосподарських культур на водний режим грунту в умовах зміни клімату.

Представлено результати досліджень впливу тривалого застосування систем основного обробітку трунту та удобрення на запаси доступної вологи рослинам в ньому. Виявлено, щзо у фазі повних сходів культур на фоні мінерального удобрення найвищими запаси доступної вологи в щарі трунту 0-20 см були за чизельної системи основного обробітку. Близьким до них були запаси за полицевої та мілкої дискової систем з показниками по 23,9 мм. На фоні органо-мінерального удобрення найвищими запаси доступної вологи в грунті (26,4 мм) були за мілкої дискової системи. У середині вегетації культур на фоні мінерального удобрення у метровому шарі трунту найвищими запаси доступної вологи (122,1 мм) були за полицевої системи. На фоні органо-мінерального удобрення запаси доступної вологи в трунті також були найвищими за полицевої системи.

На фоні мінерального удобрення урожайність гірчищі білої (1,89 m/2a) та сої (2,06 m/гa) була найвищою за полицевої системи, пшениці озимої (5,8 m/2a) та ячменю ярого (4,06 m/2a) - за плоскорізної. На фоні органо-мінерального удобрення урожайність усіх культур сівозміни була найвищуюю за полицевої системи з показниками 1,89 m/2a, 2,02 m/2a, 4,14 m/2a i 5,93 m/2a, відповідно.

Ключові слова: продуктивність, гірчиця біла, соя, пшениця озима, ячмінь ярий, шар грунту, фон живлення.

\section{Ветуп}

Забезпечити високу продуктивність сучасних сортів сільськогосподарських культур за змін клімату можна лише 3 врахуванням стресових чинників на ріст і розвиток рослин у різні фенологічні фази (Orlovskyi et al., 2019). Зміна клімату призвела до різких коливань параметрів погодних умов та прояву посушливості в період вегетації рослин, що спостерігається все частіше. За таких умов системи землеробства мають бути максимально вологоощадними. Водний режим грунту в умовах Лісостепу України є одним 3 основних чинників формування високої продуктивності агрофітоценозів сільськогосподарських культур (Litvinov, 2015; Kaminskyi \& Hanhur, 2018). Недостача вологи у грунті не лише призводить до зменшення продуктивності сортів культур, але й знижує ефективність окремих елементів їх агротехнологій вирощування. Дефіцит доступної вологи досить часто лімітує i навіть нівелює позитивний вплив добрив, обробітку грунту та інших агротехнічних заходів (Pestov, 1969; Zaharchenko \& Predko, 1975; Jakimenko et al., 1985).

Існує наукова думка, що найбільш надійним показником посухи $\epsilon$ вологість орного шару грунту. Результати вивчення водного режиму грунту i стану сільськогосподарських рослин свідчить, що зниження запасів грунтової вологи в орному шарі до 19 мм слід вважати початком посушливого періоду, а до 9 мм - початком сухого періоду. Тому періоди, протягом яких запаси продуктивної вологи в орному шарі складають менше 20 мм, відносять до посушливих, а період 3 запасом вологи менше 10 мм - до сухих (Gudz et al., 2007). За однакових метеорологічних умов вологозабезпеченість окремих сільськогосподарських культур значною мірою залежить від складу та чергування їх у сівозміні (Shapoval et al., 2002), а отже і від обробітку грунту.

Існують різні думки щодо вологонакопичувальної ефективності різних обробітків грунту. Більшість учених у своїх публікаціях впевнені в доцільності проведення безполицевих обробітків для кращого вологозабезпечення культур. Так, дискування, порівняно зі звичайною оранкою на чорноземах типових сприяло збільшенню грунтових запасів вологи на 80-320 м ${ }^{3}$ на 1 га ріллі (Viguzov, 1984). Пояснюють цю перевагу меншими втратами вологи за рахунок зменшення пористості грунту, поліпшення мікрорельєфу та збереження стерні на поверхні поля (Laukart, 1984; Cadovij, 1999; Lafond et al., 2006; Centilo, 2019). Аналогічні результати отримано на чорноземних грунтах і в інших дослідженнях (Shapoval et al., 2002; Alabuchev \& Ovcjnnikova, 2012; Korchagin et al., 2015). Можна зустріти і протилежні твердження (Rogko et al., 2018). Неоднозначність поглядів спонукала нас до вивчення цього питання стосовно систем основного обробітку грунту та удобрення. 


\section{Матеріали та методи}

Метою наших досліджень було визначення впливу різних систем основного обробітку грунту та удобрення на водний режим грунту i продуктивність сільськогосподарських культур у короткоротаційній сівозміні.

На Хмельницькій державній сільськогосподарській дослідній станції впродовж 20092018 pp. у стаціонарному досліді вивчали вплив різних систем основного обробітку грунту та удобрення на запаси продуктивної вологи у грунті та продуктивність сільськогосподарських культур. Дослідження проводили в 4-пільній сівозміні де висівали: сою, ячмінь ярий, гірчицю білу, пшеницю озиму. Агротехніка вирощування культур - загальноприйнята для зони Лісостепу де принципом єдиної відміни прийнято не глибину, а спосіб (систему) розпушення грунту.

Схема досліджуваного основного обробітку грунту включала наступні системи: полицева (контроль) де виконували щорічну оранку плугом ПЛН-3-35 на глибину 20-27 см (залежно від необхідної під культуру), плоскорізна - щорічний основний обробіток плоскорізом КПГ-2-150 на 20-27 см, чизельна - плугом чизельним ПЧ-2,5+ПСТ-2,5 на 20-27 см, мілка дискова дисками БДТ-7 на 10-12 см, мінімальна (3 2009 року) - дисками БДТ-7 на 6-8 см.

32009 року дози добрив під культури були такими: за традиційної системи удобрення (мінеральної, фон 1) - $\mathrm{N}_{60} \mathrm{P}_{60} \mathrm{~K}_{60}$, за альтернативної системи удобрення (органо-мінеральної, фон 2) - солома попередника $+\mathrm{N}_{10 / \text { г }}$ соломи + $\mathrm{N}_{30} \mathrm{P}_{30} \mathrm{~K}_{30}$.

Грунт - чорнозем опідзолений, середньосуглинковий. Уміст гумусу - 2,62-3,12\%, загального азоту - 0,150-0,163\%, рухомих фосфатів - 12,5-19,61 і калію - 6,5-7,2 мг на 100 г грунту, $\mathrm{pH}$ (сольове) - 6,0-6,5.

Розміщення ділянок - систематичне.

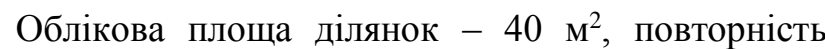
досліду - чотириразова.

Дослідження проводили за загальноприйнятими методиками (Dospyehov, 1979; Kachynckyy, 1965). Визначення запасів вологи у метровому шарі грунту проводили в основні фази росту i розвитку культур. Агрометеорологічні умови характеризувались істотним відхиленням від середньобагаторічних показників, як за кількістю опадів, температурним режимом, так $\mathrm{i}$ їх розподілом у період вегетації, що мало певний вплив на ріст і розвиток культур, але в цілому вплив досліджуваних факторів спостерігався стабільно. За роки досліджень відмічена тенденція у бік зростання як кількості опадів, так і температур.

\section{Результати досліджень та обгрунтування}

Наразі почастішали посушливі явища під час сівби як ярих, так i озимих культур, що призводить до зрідження сходів. За таких обставин посів культур без коткування не відбувається. У наших дослідженнях у фазі повних сходів культур найбільші зрідження зафіксовані на посівах пшениці озимої (до 25 \%) за полицевої (контроль) системи на фоні мінерального удобрення. За згаданих умов сходи сої були зріджені до 20 \%, гірчиці білої - до $15 \%$, ячменю ярого - до $10 \%$. За безполицевих систем густота сходів була значно вищою, особливо на фоні органо-мінерального удобрення (у середньому на 20 \% до мінерального фону). Часто відсутність вологи у посівному шарі не дозволяла виявити різницю в іiі запасах між системами обробітку грунту та фонами живлення не лише в шарі 0-5 cм, але і в 0-10 см. Тому ми спробували узагальнити цей показник за роки досліджень у шарі грунту 0-20 см (табл. 1). Встановлено, що у середньому за роки досліджень на фоні мінерального удобрення у посівах гірчиці білої найвищі запаси доступної грунтової вологи (26,9 мм) в орному шарі створювалися за полицевої системи, у посівах пшениці озимої (21,6 мм) - за мілкої дискової системи, сої (25,9 мм) - за чизельної, ячменю ярого (24,2 мм) - за чизельної. У середньому в сівозміні найвищі запаси вологи (24,2 мм) були за чизельної системи, яка переважала полицеву (контроль) на 0,3 мм (1\%). Найнижчими (22,9 мм) запаси виявилися за плоскорізної системи, що менше контролю на 1,0 мм (4\%). На фоні органомінерального удобрення у посівах гірчиці білої найвищими (29,5 мм) запаси вологи були за мілкої дискової системи, пшениці озимої (25,5 мм) - за полицевої, сої (28,1 мм) - за мілкої дискової, ячменю ярого (26,2 мм) - також за мілкої дискової. У середньому на згаданому фоні найвищі запаси вологи (26,4 мм) були за мілкої дискової системи, яка переважала контроль на 0,4 мм (2\%). 
Таблиия 1. Запаси доступної вологи у шарі грунту 0-20 см залежно від системи основного обробітку та фону живлення, середнє за 2009-2018 рр. (фаза повних сходів культур)

\begin{tabular}{|c|c|c|c|c|c|c|c|c|c|}
\hline \multirow[b]{2}{*}{$\begin{array}{l}\text { Системи } \\
\text { обробітку }\end{array}$} & \multicolumn{5}{|c|}{$\begin{array}{l}\text { Запаси доступної вологи у шарі грунту } \\
\text { 0-20 см, мм }\end{array}$} & \multicolumn{2}{|c|}{$\begin{array}{c} \pm \text { до } \\
\text { контролю }\end{array}$} & \multicolumn{2}{|c|}{$\begin{array}{c} \pm \text { до } \\
\text { фону } 1\end{array}$} \\
\hline & 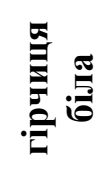 & 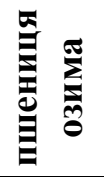 & बั & 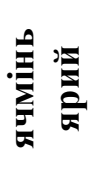 & 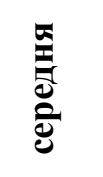 & мм & $\%$ & MM & $\%$ \\
\hline \multicolumn{10}{|c|}{ Мінеральне удобрення (фон 1) } \\
\hline $\begin{array}{l}\text { Полицева } \\
\text { (контроль) }\end{array}$ & 26,9 & 21,2 & 23,7 & 23,8 & 23,9 & - & - & - & - \\
\hline Плоскорізна & 24,5 & 21,1 & 21,9 & 24,0 & 22,9 & $-1,0$ & -4 & - & - \\
\hline Чизельна & 24,1 & 21,3 & 25,9 & 25,3 & 24,2 & 0,3 & 1 & - & - \\
\hline Мілка дискова & 24,1 & 21,6 & 25,4 & 24,4 & 23,9 & - & - & - & - \\
\hline Мінімальна & 24,8 & 20,9 & 25,5 & 21,3 & 23,1 & $-0,8$ & -3 & - & - \\
\hline \multicolumn{10}{|c|}{ Органо-мінеральне удобрення (фон 2) } \\
\hline $\begin{array}{l}\text { Полицева } \\
\text { (контроль) }\end{array}$ & 27,0 & 25,5 & 27,1 & 24,5 & 26,0 & - & - & 2,1 & 9 \\
\hline Плоскорізна & 28,4 & 22,3 & 26,9 & 26,1 & 25,9 & $-0,1$ & $-0,4$ & 3 & 13 \\
\hline Чизельна & 27,7 & 22,5 & 26,1 & 25,7 & 25,5 & $-0,5$ & -2 & 1,3 & 5 \\
\hline Мілка дискова & 29,5 & 21,6 & 28,1 & 26,2 & 26,4 & 0,4 & 2 & 2,5 & 10 \\
\hline Мінімальна & 26,0 & 22,8 & 25,7 & 24,7 & 24,8 & $-1,2$ & -5 & 1,7 & 7 \\
\hline
\end{tabular}

Важливо відмітити, що у період повних сходів культур запаси доступної грунтової вологи в орному шарі грунту на фоні органомінерального удобрення переважали мінеральний фон за усіх систем основного обробітку: від 1,3 мм (5\%) за чизельної системи до 3 мм (13\%) за плоскорізної.

Все частішими та дошкульнішими стають літні посухи. Особливу загрозу для культур вони несуть коли тривала відсутність опадів супроводжується високими температурами. Тому важливо відслідкувати вплив систем обробітку та удобрення на запаси грунтової вологи в середині вегетації культур, тобто у період цвітіння. У зв'язку з тим, що вміст вологи в грунті досить динамічний показник, особливо влітку, адже на його величину, крім опадів, впливає ще ряд факторів, ми звернули увагу на їі запаси в метровому шарі, де вони найбільш стабільні (табл. 2).

На фоні мінерального удобрення в середині вегетації культур у метровому шарі грунту в посівах гірчиці білої найвищими (132,1мм) запаси доступної грунтової вологи виявилися за полицевої системи основного обробітку грунту (контроль). Близькими до цього показника вони були за плоскорізної системи і складали 130,1 мм, а найнижчими (117,3 мм) - за мінімальної, що нижче від контролю на 14,8 мм (11\%). У посівах пшениці озимої у період цвітіння в метровому шарі найвищими $(117,4$ мм) запаси вологи були за плоскорізної системи, що більше до контролю на 4,7 мм (4 \%), найнижчими (105,3 мм), або мінус 7,4 мм (7 \%) - за мінімальної. У посівах сої у фазі цвітіння в метровому шарі грунту найвищими (126,3 мм) запаси грунтової вологи виявилися за полицевої системи (контроль), найнижчими (105,4 мм) вони були за мінімальної, що менше від контролю на 20,9 мм (17 \%). У посівах ячменю ярого в середині вегетації в метровому шарі найвищими $(117,3$ мм) запаси грунтової вологи були за полицевої системи (контроль), найнижчими (109,6 мм) - за мінімальної, що нижче контролю на 7,7 мм (7\%). Таким чином, у середині вегетації культур у середньому в сівозміні найвищі (122,1 мм) запаси грунтової вологи в метровому шарі виявлено на контролі за полицевої системи, за всіх інших систем (безполицевих) - зафіксовано зниження запасів вологи порівняно до контролю на 2-10 \% з найменшим $(109,4$ мм) значенням за мінімальної системи. 
Таблиия 2. Запаси доступної вологи у шарі грунту 0-100 см залежно від системи основного обробітку та фону живлення, середнє за 2009-2018 рр. (середина вегетації культур)

\begin{tabular}{|c|c|c|c|c|c|c|c|c|c|}
\hline \multirow{3}{*}{$\begin{array}{l}\text { Системи } \\
\text { обробітку }\end{array}$} & \multicolumn{5}{|c|}{$\begin{array}{l}\text { Запаси доступної вологи у шарі грунту } \\
0-100 \text { см, мм }\end{array}$} & \multirow{2}{*}{\multicolumn{2}{|c|}{$\begin{array}{c} \pm д о \\
\text { контролю }\end{array}$}} & \multirow{2}{*}{\multicolumn{2}{|c|}{$\begin{array}{c} \pm \text { до } \\
\text { фону } 1\end{array}$}} \\
\hline & \multirow{2}{*}{ 疍 } & \multirow{2}{*}{ 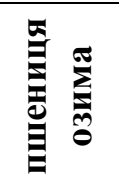 } & \multirow[b]{2}{*}{ ड્ } & \multirow{2}{*}{ 悬 } & \multirow{2}{*}{ 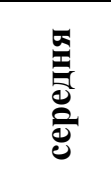 } & & & & \\
\hline & & & & & & мM & $\%$ & мM & $\%$ \\
\hline \multicolumn{10}{|c|}{ Мінеральне удобрення (фон 1) } \\
\hline $\begin{array}{l}\text { Полицева } \\
\text { (контроль) }\end{array}$ & 132,1 & 112,7 & 126,3 & 117,3 & 122,1 & - & - & - & - \\
\hline Плоскорізна & 130,1 & 117,4 & 105,4 & 126,5 & 119,9 & $-2,2$ & $-1,8$ & - & - \\
\hline Чизельна & 120,9 & 111,6 & 117,8 & 111,3 & 115,4 & $-6,7$ & -5 & - & - \\
\hline Мілка дискова & 123,1 & 107,1 & 109,5 & 111,2 & 112,7 & $-9,4$ & -8 & - & - \\
\hline Мінімальна & 117,3 & 105,3 & 105,4 & 109,6 & 109,4 & $-12,7$ & -10 & - & - \\
\hline \multicolumn{10}{|c|}{ Органо-мінеральне удобрення (фон 2) } \\
\hline $\begin{array}{l}\text { Полицева } \\
\text { (контроль) }\end{array}$ & 141,2 & 124,6 & 122,6 & 128,2 & 129,2 & - & - & 7,1 & 6 \\
\hline Плоскорізна & 127,1 & 112,1 & 115,0 & 125,3 & 119,9 & $-9,3$ & -7 & - & - \\
\hline Чизельна & 126,6 & 110,2 & 115,1 & 113,3 & 116,3 & $-12,9$ & -10 & 0,9 & 1 \\
\hline Мілка дискова & 129,0 & 104,7 & 108,6 & 115,2 & 114,4 & $-14,8$ & -11 & 1,7 & 2 \\
\hline Мінімальна & 114,2 & 103,5 & 103,5 & 106,4 & 106,9 & $-22,3$ & -17 & $-2,5$ & -2 \\
\hline
\end{tabular}

На фоні органо-мінерального удобрення в метровому шарі грунту в середині вегетації культур у посівах гірчиці білої найвищі (141,2 мм) запаси доступної грунтової вологи виявлено за полицевої (контроль) системи основного обробітку, найнижчі (114,2 мм) вони були за мінімальної, що менше від контролю на 27 мм (19\%). У посівах пшениці озимої в середині вегетації в метровому шарі грунту найвищі (124,6 мм) запаси грунтової вологи виявлено за полицевої (контроль) системи основного обробітку, найнижчі (103,5 мм) - за мінімальної, що менше від контролю на 21,1 мм (17\%). У посівах сої в середині вегетації в метровому шарі грунту найвищими $(122,6$ мм) запаси грунтової вологи виявилися за полицевої системи (контроль), найнижчими (103,5 мм) вони були за мінімальної, що менше від контролю на 19,1 мм $(16 \%)$. У посівах ячменю ярого в середині вегетації в метровому шарі найвищими (128,2 мм) запаси грунтової вологи були за полицевої системи (контроль), найнижчими (106,4 мм) - за мінімальної, що нижче контролю на 21,8 мм (17 \%). Таким чином, у середині вегетації культур у середньому в сівозміні найвищі (129,2 мм) запаси грунтової вологи в метровому шарі грунту виявлено на контролі за полицевої системи, а за всіх безполицевих систем обробітку грунту відмічено зниження запасів вологи порівняно до контролю на $2-17 \% 3$ найменшим (106,9 мм) значенням за мінімальної системи. Отже, в середині вегетації культур в метровому шарі грунту на фоні органо-мінерального удобрення, порівняно до мінерального, за полицевої системи виявлено вищі запаси доступної грунтової вологи на 7,1 мм (6\%), за чизельної - на 0,9 мм (1\%), за мілкої дискової - на 1,7 мм (2 \%). За мінімальної системи запаси вологи в метровому шарі виявилися нижчими до мінерального фону на 2,5 мм (2\%), за плоскорізної - однаковими на обох фонах.

Показником оцінки різних систем основного обробітку грунту є продуктивність сільськогосподарських культур. Системи основного обробітку грунту виявили істотний вплив на урожайність культур сівозміни (табл. 3). Так, на фоні мінерального удобрення найвищу врожайність гірчиці білої $(1,89$ т/га) отримали за полицевої системи (контроль), найнижчу (1,55 т/га) - за мінімальної, що нижче контролю на 0,34 т/га (18\%). 
Таблищя 3. Продуктивність культур сівозміни залежно від системи основного обробітку грунту та фону живлення, (2009-2018 рр.), т/га

\begin{tabular}{|c|c|c|c|c|c|c|c|c|c|}
\hline \multirow{2}{*}{$\begin{array}{c}\text { Системи } \\
\text { обробітку }\end{array}$} & \multirow{2}{*}{ 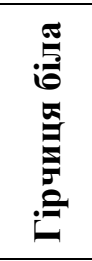 } & \multirow{2}{*}{ 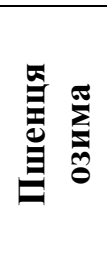 } & \multirow{2}{*}{ ن் } & \multirow{2}{*}{ 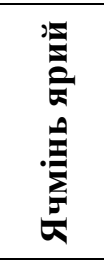 } & \multirow{2}{*}{ ن̃ } & \multicolumn{2}{|c|}{$\begin{array}{c} \pm \text { до } \\
\text { контролю }\end{array}$} & \multicolumn{2}{|c|}{$\begin{array}{c} \pm \text { до } \\
\text { фону } 1\end{array}$} \\
\hline & & & & & & $\mathbf{T} / \mathbf{\Gamma a}$ & $\%$ & $\mathbf{T} / \mathbf{r a}$ & $\%$ \\
\hline \multicolumn{10}{|c|}{ Мінеральне удобрення (фон 1) } \\
\hline Полицева (контроль) & 1,89 & 5,74 & 2,06 & 3,97 & 3,42 & - & - & - & - \\
\hline Плоскорізна & 1,85 & 5,80 & 1,80 & 4,06 & 3,38 & $-0,04$ & -1 & - & - \\
\hline Чизельна & 1,77 & 5,53 & 2,00 & 3,64 & 3,24 & $-0,18$ & -5 & - & - \\
\hline Мілка дискова & 1,80 & 5,37 & 1,92 & 3,61 & 3,18 & $-0,24$ & -7 & - & - \\
\hline Мінімальна & 1,55 & 5,19 & 1,73 & 3,39 & 2,97 & $-0,45$ & -13 & - & - \\
\hline \multicolumn{10}{|c|}{ Органо-мінеральне удобрення (фон 2) } \\
\hline Полицева (контроль) & 1,89 & 5,93 & 2,02 & 4,14 & 3,50 & - & - & 0,08 & 2 \\
\hline Плоскорізна & 1,83 & 5,67 & 1,94 & 4,04 & 3,37 & $-0,13$ & -4 & $-0,01$ & $-0,3$ \\
\hline Чизельна & 1,82 & 5,37 & 1,98 & 3,65 & 3,21 & $-0,29$ & -8 & $-0,03$ & -1 \\
\hline Мілка дискова & 1,83 & 5,17 & 1,83 & 3,68 & 3,13 & $-0,37$ & -11 & $-0,05$ & -2 \\
\hline Мінімальна & 1,50 & 5,05 & 1,58 & 3,23 & 2,84 & $-0,66$ & -19 & $-0,13$ & -4 \\
\hline
\end{tabular}

У середньому за роки досліджень урожайність пшениці озимої була найвищою $(5,8$ т/га) за плоскорізної системи обробітку грунту, що на 0,06 т/га більше порівняно 3 оранкою. За мінімальної системи обробітку грунту отримано урожайність зерна $-5,19$ т/га, що менше на 0,61 т/га (11\%) порівняно $з$ полицевою системою. Урожайність сої була найвищою (2,06 т/га) за полицевої системи (контроль), найнижчою - 1,73 т/га, або мінус 0,33 т/га (16\%) від контролю за мінімальної.

Урожайність ячменю ярого у середньому за роки досліджень була найвищою (4,06 т/га) за плоскорізної системи обробітку грунту, що склало 0,09 т/га приросту до контролю, а найнижчою $(3,39$ т/га) - за мінімальної, що становило недобір урожаю 0,58 т/га (15\%) до контролю. На фоні органо-мінерального удобрення урожайність усіх культур виявилась найвищою за полицевої системи (контроль) і складала: гірчиці білої - 1,89 т/га, пшениці озимої 5,93 т/га, сої - 2,02 т/га, ячменю ярого - 4,14 т/га. Найнижчою урожайність згаданих культур була за мінімальної системи 3 показниками: 1,50 т/га, 5,05 т/га, сої - 1,58 т/га, 3,23 т/га, відповідно. В цілому, урожайність усіх культур сівозміни за всіх безполицевих систем виявилася нижчою від полицевої (контролю) на 4-19\%. За органомінерального удобрення встановлено приріст урожайності $2 \%$ лише за полицевої системи порівняно до фону мінерального живлення, а за безполицевих - зниження на $0,3-4 \%$. На фоні органо-мінерального удобрення за полицевої системи обробітку грунту лише в посівах сої відмічено неістотне зниження на 0,04 т/га (2\%) урожайності зерна порівняно до мінерального. Нами виявлено прямі кореляційні залежності між запасами доступної грунтової вологи в метровому шарі грунту в середині вегетації культур i показниками урожайності: на фоні мінерального удобрення - 0,553-0,878, та органо-мінерального $0,924-0,997$.

\section{Висновки}

1. У орному шарі грунту найвищими запаси доступної вологи $(23,9-24,2$ мм) у період повних сходів культур сівозміни були на фоні мінерального удобрення за чизельної, полицевої та мілкої дискової систем обробітку грунту, а найменшими (22,9 мм) за плоскорізної.

2. Застосування полицевої та мілкої дискової системи на органо-мінеральному фоні живлення забезпечили найвищі запаси доступної вологи в 
грунті. На згаданому фоні запаси продуктивної вологи збільшились на 5-13\% порівняно 3 мінеральним фоном живлення.

3. Запаси доступної вологи у метровому шарі грунту на фоні мінерального удобрення були найвищими (122,1мм) за полицевої системи. Застосування безполицевих систем обробітку грунту призвело до зменшення згаданого показника на 2-10 \% порівняно 3 оранкою.

4. За органо-мінерального удобрення запаси доступної вологи у метровому шарі грунту були найвищими (129,2 мм) за полицевої системи, що на $6 \%$ більше порівняно 3 мінеральним фоном. Встановлено зниження запасів продуктивної вологи в грунті на 7-17\% за безполицевих систем, порівняно 3 контролем.

5. Встановлено, що на фоні мінерального удобрення урожайність гірчиці білої $(1,89$ т/га) та coї (2,06 т/га) була найвищою за полицевої системи обробітку грунту, а ячменю ярого (4,06 т/га) та пшениці озимої (5,8 т/га) - за плоскорізної системи. За органо-мінерального удобрення урожайність усіх досліджуваних культур сівозміни була найвищою за полицевої системи обробітку грунту.

\section{References}

Alabushev, A. B. \& Ovsyannikova, G.V. (2012). Vlagoobespechennost pochvy i vodopotrebleniye ozimoy pshenitsy $\mathrm{v}$ polevom sevooborote [Moisture providing of soil and moisture requirement of winter wheat is in the field crop rotation]. Zemledeliye, 5, 10-12 [in Russian].

Dospekhov, B. A. (1979). Metodika polevogo opyta [Method of field experiment]. Moskva. Kolos [in Russian].

Horobets, A. H., Tsyliuryk, O. I., Horbatenko, A. I. \& Sudak, V. M. (2011). Volohozabezpechenist ta urozhainist polovykh kultur za riznykh system obrobitku gruntu $\mathrm{v}$ sivozmini [Moisture providing and productivity of the field cultures at the different systems of till of soil that in a crop rotation]. Biuleten Instytutu silskoho hospodarstva stepovoi zony, 1, 2025 [in Russian].

Hudz, V. P., Prymak, I. D. \& Rybak, M. F. (2007). Adaptyvni systemy zemlerobstva [Adaptive systems of agriculture]. Kyiv: Tsentr uchbovoi literatury [in Russian].

Kachinskiy, N. A. (1965). Fizika pochv [The physics of soil]. Novosibirsk [in Russian].

Kaminskyi, V. F. \& Hanhur, V. V. (2018). Dynamika produktyvnoi volohy $\mathrm{V}$ grunti za vyroshchuvannia pshenytsi ozymoi v sivozminakh Livoberezhnoho Lisostepu Ukrainy [Dynamics of productive moisture in the soil for the cultivation of winter wheat in the crop rotations of the Left-Bank Forest-Steppe of Ukraine]. Visnyk Poltavskoi derzhavnoi ahrarnoi akademii, 3, 11-14. doi: https://doi.org/10.31210/visnyk2018.03.01 [in Ukrainian].

Korchagin, A. A., Ilin, L. I. \& Bibik, T. C. (2015). Vliyaniye sistem obrabotki na vodnyy rezhim seroy lesnoy pochvy [Influence of the systems of till is on the water mode of grey forest soil]. Zemledeliye, 8, 22-25 [in Russian].

Lafond, G. P., May, W. E., Stevenson, F. C. \& Derksen, D. A. (2006). Effects of tillage systems and rotations on crop production for a thin Black Chernozem in the Canadian Prairies. Soil and Tillage Research, 89 (2), 232-245.

Laukart, F. F. (1984). Effektivnost minimalizatsii osenney obrabotki pochvy i borba s sornyakami [Effectiveness in minimizing autumn tillage and weed control]. Zemledeliye, 9, 13-14 [in Russian].

Litvinov, D. V. (2015). Formuvannia vodnoho rezhymu gruntu $\mathrm{V}$ systemi korotkorotatsiinykh sivozmin [Formation of water regime of soil in system of short crop rotations]. Visnyk ahrarnoi nauky, 11, 13-18 doi: https://doi.org/10.31073/agrovisnyk201511-03 [in Ukrainian].

Orlovskyi, M. Y., $\quad$ Tymoshchuk, T. M., Konopchuk, O. V., Voitsekhivskyi, V. I., \& Didur, I. M. (2019). Vplyv elementiv tekhnolohii vyroshchuvannia na produktyvnist pshenytsi ozymoi v umovakh Zakhidnoho Polissia Ukrainy [Influence of elements of technology of growing on the productivity of winter wheat in the conditions of the Western Polissy of Ukraine]. Scientific Horizons, 1 (74), 18-24. doi: https://doi.org/10.332491/26632144-2019-74-1-18-24 [in Ukrainian].

Pestov, I. I. (1969). Vplyv poperednykiv na vodnyi ta pozhyvnyi rezhymy hruntu, rist ta rozvytok tsukrovykh buriakiv, produktyvnist lanok sivozmin [Influence of predecessors is on the water and nourishing modes of soil, height and development of sugar beets, productivity of links of crop rotations]. Zemlerobstvo, 20, 25-29 [in Ukrainian].

Rozhko. V. M., Pelykh, A. Yu. \& Borys, N. Ye. (2018). Vplyv system osnovnoho obrobitku hruuntu na zapas produktyvnoi volohy v posivakh kukurudzy na zerno [Influence of the systems of basic till of груунту on the supply of productive moisture in sowing of corn on grain]. Klimatychni zminy ta silske 
hospodarstvo, Zbirnyk tez mizhnarodnoi naukovopraktychnoi konferentsii za uchastiu FAO (pp. 430433). Kyiv : NMTs «Ahroosvita» [in Russian].

Sadovyi, S. O. (1999). Vplyv bezpolytsevykh sposobiv osnovnoho obrobitku gruntu na umovy rostu ta produktyvnist lanky sivozminy chystyi parozyma pshenytsia-kukurudza na zerno [Influence of nonmoldboard methods в of basic till of soil on the terms of dewsthat and the productivity of link of crop rotation clean pairs - a winter wheat is a corn on grain]. Visnyk Kharkivskoho derzhavnoho ahrarnoho universytetu, 1, 102-105 [in Ukrainian].

Shapoval, I. S., Shylina, L. I. \& Kovalenko, N. P. (2002). Vodnyi rezhym hruntu zalezhno vid nasychennia sivozmin zernovymy kulturamy [Moisture regime of soil depending on satiation crop rotation of grain crop]. Zbirnyk naukovykh prats Instytutu zemlerobstva UAAN, 3, 44-47.

Tsentylo, L. V. (2019). Zmina vodnorho rezhymu chornozemu typovoho zalezhno vid system osnovnoho obrobitku hruntu [Change of the воднорго mode of black earth of typical depending on the systems basic till of soil]. Visnyk ahrarnoi nauky, 11, 22-27 [in Ukrainian].

Vyguzov, Yu. I. (1984). Obrabotka sklonovykh zemel na Urale [Till of slope earth is on Ural]. Zemledeliye, 5, 10-12 [in Russian].

Yakimenko, V. N., Shkarednyy, I. S. \& Odrekhovskiy, A. F. (1985). Vlagoobespechennost polya [Moisture providing of field]. Sakharnaya svekla, 11, 21-23 [in Russian].

Zakharchenko, I. H. \& Predko, I. H. (1975). Vodnyi rezhym hruntu v zerno-buriakovii sivozmini livoberezhnoho Lisostepu Ukrainskoi RSR [The water mode of soil is in the grain - beet crop rotation of left-bank Forest-steppe of Ukrainian SSR]. Zemlerobstvo, 41, 28-36 [in Russian]. 